Research Article

Journal of Extension Education

Vol. 30 No. 4, 2018

DOI:https://doi.org/10.26725/JEE.2018.4.30.6177-6182

\title{
Attitude of Farmers towards Eco - friendly Farming Practices in The Nilgiris, Tamil Nadu
}

\section{Muralikrishnan ${ }^{1}$ and H. Philip ${ }^{2}$}

\begin{abstract}
The farm lands in the Western Ghats ecosystem of India had been losing its fertility, bio diversity and ecological uniqueness due to long use of chemical fertilizers, commercial farm management practices and chemical pesticides. To solve these issues, adopting eco-friendly farming practices is one of the major solutions. The study aimed to analyse the attitude of farmers in Western ghats towards eco-friendly conservation practices. Majority of the farmers had moderately favorable attitude towards eco -friendly farming practices. Regression analysis suggested that the leadership abilities and contact with extension agency had significant contribution with the attitude level of farmers towards the eco-friendly farming practices.
\end{abstract}

Keywords: Attitude; Eco-friendly farming practices; Western ghats; The Nilgiris

\section{INDRODUCTION}

The long-term implications of estate and plantation agriculture have been created ecological problems due to long use of chemical fertilizers, commercial farm management practices and chemical pesticides. This creates a hazardous situation for agro biodiversity Agricultural biodiversity a vital sub-set of biodiversity, is a creation of humankind whose food and livelihood security depend on the sustained management of those diverse biological resources that are important for food and agriculture (Ramakrishnan, 2002). In this context, the eco-friendly farming practices minimize the agricultural production risks and conserve the sustainable management of the Western Ghats ecosystem.
Eco friendly farming practices is a holistic production management system which promotes and enhances agro-ecosystem health, including biodiversity, biological cycles and soil biological activity (FAO, 1999),

The Western Ghats plays a significant role in determining the climate and physiography of India, spreading over six states namely Gujarat, Maharashtra, Karnataka, Kerala, Goa and Tamil Nadu. It has a wide range of vegetation and topographical features. Unfortunately during the $19^{\text {th }}$ century, large tracts of forest lands of the Western Ghats region were cleared and converted the land for commercial agriculture practices of tea, coffee, exotic vegetables likes potato, carrot, etc.

1. Scientist, Division of Agricultural Extension, ICAR-IARI, New Delhi-110012 and 2, Director of Extension Education, TNAU, Coimbatore-641003

Received : 13-07-2018; Accepted : 12-02-2019 
The present study aimed to assess the attitude and of farmers towards eco-friendly farming practices in the Nilgiris district in Western ghats of Tamil Nadu.

\section{METHODOLOGY}

The study was conducted purposively in The Nilgiris district Tamil Nadu and data were collected by using an interview schedule. All four blocks of the district were taken for this study. A sample of 80 farmers was selected from each block. Altogether, 320 respondents were selected from the district, based on simple random sampling technique with the support of the State department of horticulture. In order to measure the attitude of farmers towards eco-friendly farming practices, a scale was constructed by following 'Equal Appearing Interval' scaling technique developed by Thurstone and Chave (1929).

\section{FINDINGS AND DISCUSSION}

\section{Construction of Attitude Scale}

Possible statements concerning the psychological object i.e., 'Eco friendly farming practices' were collected based on the review of literature and discussion with social scientists, agronomists and environmental scientists. Altogether 62 statements were collected which were organized and structured in the form of attitude items. The items were screened by following informal criteria. Based

Table 1.

Final Set of Attitude items Selected with Corresponding S and Q values and the Nature of Statements

\begin{tabular}{|c|c|c|c|l|c|}
\hline $\begin{array}{c}\text { Sl. } \\
\text { No. }\end{array}$ & $\begin{array}{c}\text { Statement } \\
\text { No. }\end{array}$ & $\begin{array}{c}\text { Scale } \\
\text { Value }\end{array}$ & $\begin{array}{c}\text { Q } \\
\text { Value }\end{array}$ & \multicolumn{1}{|c|}{ Statement } & $\begin{array}{c}\text { Nature of the } \\
\text { statement }\end{array}$ \\
\hline 1. & 42 & 4.23 & 1.31 & $\begin{array}{l}\text { Eco friendly farming practices will not } \\
\text { get support from family members }\end{array}$ & Unfavourable \\
\hline 2. & 24 & 2.61 & 2 & $\begin{array}{l}\text { Eco friendly farming practices are } \\
\text { market need oriented }\end{array}$ & Favourable \\
\hline 3. & 54 & 4.11 & 1.17 & $\begin{array}{l}\text { Eco friendly farming practices do } \\
\text { not attract youth towards livelihood } \\
\text { security }\end{array}$ & Unfavourable \\
\hline 4. & 33 & 4 & 1.38 & $\begin{array}{l}\text { Forest department schemes are } \\
\text { encouraging eco-friendly farming } \\
\text { practices }\end{array}$ & Favourable \\
\hline 5. & 49 & 4.15 & 0.09 & $\begin{array}{l}\text { Participation in eco-friendly farming } \\
\text { Practices is very much encouraging }\end{array}$ & Favourable \\
\hline 6. & 15 & 4.15 & 1.08 & $\begin{array}{l}\text { Eco friendly farming practices reduces } \\
\text { the environmental uncertainties }\end{array}$ & Favourable \\
\hline 7. & 2 & 4.76 & 0.94 & $\begin{array}{l}\text { Eco friendly farming practices protect } \\
\text { bio diversity }\end{array}$ & Favourable \\
\hline
\end{tabular}


Attitude of Farmers towards Eco - friendly Farming Practices in The Nilgiris, Tamil Nadu

Table 2. Distribution of Respondents based on their Attitude Level towards Eco-friendly Farming Practices

$(n=320)$

\begin{tabular}{|c|l|c|c|}
\hline SI. No. & \multicolumn{1}{|c|}{ Attitude of farmers } & Number & Percentage \\
\hline 1. & Less favorable & 76 & 23.75 \\
\hline 2. & Moderately favorable & 177 & 55.31 \\
\hline 3. & Highly favorable $\quad$ Total & 320 & 20.94 \\
\hline & \multicolumn{2}{r}{} \\
\hline
\end{tabular}

on the screening, 55 items were selected which formed the universe of the content. The 55 statements were then subjected to judges' opinion on a five point continuum, ranging from most favorable to most unfavorable.

The list of statements was sent to 50 judges comprising extenionists of State Agricultural Universities of Tamil Nadu, Kerala, Andhra Pradesh and Karnataka. Of the 50 judges, 40 judges responded by sending their judgements. By applying the formula as suggested by Thurstone and Chave (1929), the scale values and $Q$ values were computed for the 40 statements. Finally the seven statements having high scale values and low $Q$ values were selected. Final set of attitude items selected with corresponding $\mathrm{S}$ and $Q$ values and the nature of statements are presented in Table 1. This attitude scale was used to measure the attitude of the farmers towards the eco- friendly farming practices in the Nilgiris district of Tamil Nadu.

\section{Attitude Level of Farmers}

Attitudes are formed by what an individual perceives to be true about the attitude-object. (Willock et al., 1999). It refers to "a person's evaluation of any psychological object.
From Table 2, it could be seen that more than half of respondents (55.31\%) were found to possess a moderately favourable attitude towards the Eco Friendly Conservation Practices followed by 23.75 per cent of the respondents with less favourable and 20.94 per cent who had highly favourable attitude towards the Eco Friendly farming Practices.

Though more than half of the farmers had moderately favourable attitude towards the eco- friendly farming practices, their awareness, knowledge and economic motivation level had affected their symbolic adoption behavior of the farmers to of eco-friendly farming practices. Training programmes, exposure visits, case studies approach, participatory extension approach and farmer led extension approaches are some suggested solutions to improve their attitude level towards the adoption of the eco-friendly farming practices in their farm lands.

\section{Association and Contribution of Farmers' Charasteristics with Attitude.}

It could be observed from Table 3 that the variable, 'leadership abilities of farmers' had a positive and significant relationship with the attitude towards Eco Friendly Conservation 
Table 3.

Association and Contribution of Farmers' Characteristics with Attitude towards Eco Friendly Farming Practices

\begin{tabular}{|c|c|c|c|c|c|}
\hline \multirow[b]{2}{*}{$\begin{array}{l}\text { Sl. } \\
\text { No. }\end{array}$} & \multirow[b]{2}{*}{ Profile characteristics } & \multicolumn{4}{|c|}{ Respondents } \\
\hline & & Correlation $r$ & $\begin{array}{l}\text { Regression } \\
\text { ('b' value) } \\
\text { coefficient }\end{array}$ & SE of $b$ & ' $t$ ' value \\
\hline 1. & (X1) Age & 0.063 & 0.008 & 0.078 & 0.100 \\
\hline 2. & (X2) Educational status & $0.350^{* *}$ & 0.059 & 0.036 & 1.647 \\
\hline 3. & (X3) Occupational status & $0.175^{* *}$ & -0.069 & 0.046 & -1.510 \\
\hline 4. & (X4) Farming experiences & -0.015 & 0.061 & 0.080 & 0.768 \\
\hline 5. & (X5) Farm size & 0.017 & -0.053 & 0.072 & -0.732 \\
\hline 6. & (X6) Annual income & -0.027 & 0.028 & 0.064 & 0.439 \\
\hline 7. & (X7) Social participation & $0.365^{* *}$ & -0.046 & 0.049 & -0.928 \\
\hline 8. & (X8) Economic motivation & $-0.385^{* *}$ & -0.063 & 0.065 & -0.974 \\
\hline 9. & (X9) Risk orientation & $0.299^{* *}$ & -0.091 & 0.096 & -0.946 \\
\hline 10. & (X10) Scientific orientation & $0.510^{* *}$ & 0.099 & 0.078 & 1.272 \\
\hline 11. & $\begin{array}{l}\text { (X11) Information seeking } \\
\text { behavior }\end{array}$ & $0.361^{* *}$ & 0.033 & 0.091 & 0.366 \\
\hline 12. & (X12) Training undergone & $0.467^{* *}$ & 0.100 & 0.082 & 1.221 \\
\hline 13. & (X13) Progressiveness & $0.334^{* *}$ & 0.023 & 0.085 & 0.275 \\
\hline 14. & $\begin{array}{l}\text { (X14) Perception on } \\
\text { environmental degradation }\end{array}$ & $0.370^{* *}$ & 0.122 & 0.106 & 1.152 \\
\hline 15. & $\begin{array}{l}\text { (X15) Perception on } \\
\text { environmental conservation }\end{array}$ & $0.558^{* *}$ & 0.061 & 0.077 & 0.800 \\
\hline 16. & (X16) Innovativeness & $0.564^{* *}$ & 0.084 & 0.060 & 1.391 \\
\hline 17. & (X17) Self reliance & $0.568^{* *}$ & 0.064 & 0.058 & 1.112 \\
\hline 18. & $\begin{array}{l}\text { (X18) Contact with extension } \\
\text { agency }\end{array}$ & $0.486^{* *}$ & 0.053 & 0.029 & $1.822^{*}$ \\
\hline 19. & (X19) Socio cultural linkage & $-0.411^{* *}$ & 0.010 & 0.068 & 0.152 \\
\hline 20. & (X20) Leadership abilities & $0.617^{* *}$ & 0.289 & 0.079 & $3.658^{* *}$ \\
\hline
\end{tabular}

$R^{2}=0.514 \quad F=11.592 \quad$ Constant $=0.239$

${ }^{*} P<0.05$ - Significant at 5 per cent level; ${ }^{* *} P<0.01$ Significant at 1 per cent level; NS-Non-significant; NA-Not applicable 
Attitude of Farmers towards Eco - friendly Farming Practices in The Nilgiris, Tamil Nadu

Practices at one per cent level of probability. The 'contact with extension agency' of the farmers too had positive and significant relationship with attitude at five per cent level.

All the selected twenty variables acted as cause to bring 51.40 per cent variation in attitude level of farmers in the Eco Friendly Conservation Practices. The prediction equation fitted for adoption of eco friendly conservation practices.

Attitude level of farmers towards Eco Friendly Conservation Practices in The Nilgiris District of Western Ghats $(\mathrm{Y})=0.239+0.008$ $(X 1)+0.059(X 2)-0.069(X 3)+0.061(X 4)-$ $0.053(X 5)+0.028(X 7)-0.046(X 7)-0.063$ (X8) --0.091 (X9) - 0.099 (X10) + 0.033 (X11) $-0.100(X 12)+0.023(X 13)+0.122(X 14)$ $+0.061(X 15)+0.084(X 16)+0.064(X 17)$ $+0.053(X 18)+0.010(X 19)+0.289(X 20)$

This revealed that a one unit increase in contact with extension agency and leadership abilities, ceteris paribus would result in an increase of 1.822 units, 3.658 units, in the overall attitude towards the eco friendly conservation practices.

It could be further observed from Table 3 that among the 20 variables, contact with extension agency and leadership abilities were found to have positively contributed to the attitude of the eco-friendly farming practices. In general, contact with extension agency and leadership abilities were the key elements in formation of attitude. The leadership abilities motivate the farmers and provides confidence in adoption of eco - friendly farming practices.
Contact with extension agency helps the farmer to build formal and informally known technology transfer mechanism with the relevance of the eco-friendly farming practices (Muralikrishnan et al 2015). It is very important to change the attitude of the farmers to adopt eco-friendly farming practices

\section{CONCLUSION}

Attitude plays a very important role in the adoption process in the eco-friendly farming practices in the Nilgiris district of Tamil Nadu. The eco-friendly farming practices are an effective and holistic system of farming practices for environmental friendly, economically viable, and socially acceptable way of adoption process. The present study revealed that the farmers of The Nilgiris district possessed moderately favourable attitude towards eco friendly farming practices. In general, it was revealed that increased contact with extension agency and identification \& promotion of leadership abilities would result in enhanced level of opinion leadership towards eco friendly conservation practices and faster adoption of eco friendly conservation practices.

\section{REFERENCES}

FAO. (1999). Organic Agriculture, Food and Agriculture Organization of the United Nations, Rome.

Muralikrishnan, L, Philip, H, Ravichandran, V \& Chinnadurai, M. (2015). Adoption \& impact of eco-friendly conservation practices in the Nilgiris district of Western Ghats. Journal of Extension Education, 27(2) 
Thurstone, L.L. \& Chave, E.J. (1929). The Measurement of Attitude. Chicago University, Chicago Press.

Willock, J., Deary, I.J., Edwards-Jones, J., Gibson, G.J., McGeregor, M.J., Sutherland, A., Dent, J.B., Morgan, O \&
Grieve, R. (1999). The role of attitude and objectives in farmer decision making: Business and environmentallyoriented behavior in Scotland, Agricultural Economics, 50 (2): 286-303. 